Resumen por los autores, G. B. Wislocki y T. J. Putnam.

La absorción en los ventrículos de hidrocéfalos internos producidos experimentalmente.

Los autores han producido hidrocéfalos en algunos gatos y conejos jóvenes mediante inyección de una suspensión de negro de humo en las cisterna cerebelo-medular. Más tarde inyectaron en los ventrículos dilatados una solución muy difusible o un colorante coloidal. Los experimentos demuestran que la absorción se lleva a cabo con cierta intensidad en los animales hidrocéfalos desde los ventrículos, y que la ruta seguida es a través del epéndimo, penetrando en los espacios intercelulares y finalmente en los espacios perivasculares. La rapidez de difusión de una verdadera solución (ferrocianuro potásico y citrato ferro-amónico) desde las cámaras cerebrales hasta la substancia cerebral es bastante rápida, pero la de una solución coloidal (azul tripan) es algo más lenta. Los autores no han llevado a cabo observaciones sobre la rapidez de la absorción de substancias extrañas por los capilares. Tampoco han encontrado prueba alguna sobre la absorción por los plexos coroideos.

Translation by José F. Nonidez

Cornell Medical College, New York 


\title{
ABSORPTION FROM THE VENTRICLES IN EXPERI- MENTALLY PRODUCED INTERNAL HYDROCEPHALUS
}

\author{
G. B. WISLOCKI AND T. J. PUTNAM \\ Laboratory of Surgical Research, Harvard Medical School \\ FOUR FICURES
}

Internal hydrocephalus has been produced experimentally in several ways. Dandy and Blackfan ('13, '14) reported the successful production of an obstructive hydrocephalus in dogs following the introduction of pledgets of cotton into the aqueduct of Sylvius. Thomas ('14) described an internal hydrocephalus produced in dogs by the intraventricular injection of aleuronate. The aleuronate caused a sterile inflammatory reaction which occluded the ventricular cavities at one or more points and prevented the escape of the cerebrospinal fluid into the subarachnoid space. Subsequently, Dandy ('19) produced a communicating type of hydrocephalus by placing strips of gauze, saturated with iodine, about the mesencephalon.

Recently, Weed ('20) described the results of his experiments on a series of young and adult cats. He was able to produce an internal hydrocephalus with great facility by injecting a suspension of lampblack into the cisterna cerebellomedullaris through a puncture in the occipito-atlantoid ligament. It was found that the lampblack caused a sterile meningitis about the rhombencephalon, thereby gradually occluding the foramina in the roof of the fourth ventricle and preventing the escape of cerebrospinal fluid into the subarachnoid space. Hydrocephalus was also produced by intraventricular injections of the lamp black.

Weed's experiments on kittens in which the fontanelles had not united are mainly of interest. In these animals hydrocephalus developed extremely rapidly and the dilatation of the ventricles 
and enlargement of the head were quite remarkable. An extreme dilatation of the ventricles and thinning of the cortex were frequently observed within ten days.

The present study was undertaken to determine whether substances injected into the dilated and occluded ventricles undergo absorption and, if they do, how they escape from the ventricles into the tissues of the brain. This question has to some extent been considered by several of the previous investigators. Dandy and Blackfan ('13, '17) described the results of injecting phenolsulphonephthalein into the ventricles of fifteen human beings suffering from internal hydrocephalus of the obstructive type. After injection the time of appearance and the amount of the drug in the urine were noted. They found that after injection of phenolsulphonephthalein into the dilated ventricles from 0.5 to 2 per cent of the drug was excreted in the urine within the first two hours. Excretion of the dye commenced from 20 to 45 minutes after injection and continued for many days. Their conclusion is that in obstructive hydrocephalus practically no absorption takes place from the ventricles.

In the present study hydrocephalus was established experimentally in animals, and several substances, the absorption of which could be studied histologically, were subsequently injected into the dilated ventricles. A solution of potassium ferrocyanide and iron ammonium citrate, which can be readily precipitated as Prussian blue in the tissues, and trypan blue, were selected for injection into the dilated ventricles. The method chosen for producing the hydrocephalus was the one described by Weed because the technique is relatively simple and hydrocephalus develops promptly.

The experiments were performed upon kittens and young rabbits. A total of twenty-five animals was used, consisting of fifteen kittens and ten rabbits. The kittens ranged in age from two to six weeks, the rabbits from one to three weeks. Weed's technique was closely adhered to. A 5 to 10 per cent suspension of lampblack in physiological salt solution was prepared. The animals were anesthetized, the skin shaved, and a needle inserted through the occipito-atlantoid ligament into the cisterna cere- 
bellomedullaris. The kittens received $1 \frac{1}{4}$ cc., the rabbits $\frac{1}{2}$ cc. of lampblack suspension. The immediate mortality from this procedure was rather high and due, as far as could be ascertained, either to injury to the rhombencephalon or to respiratory failure from the sudden increase in pressure on the medulla.

The animals surviving the injection recovered from either and appeared normal in all respects. The day following theinjection nothing unusual could be observed. The first signs of a developing hydrocephalus could be made out on the second, more often on the third or fourth day. Gradually the enlargement of the cranial vault became noticeable and a diastasis of the cranial sutures could be made out. The animals' behavior changed somewhat. Slight ataxia was nearly always noted and tremors were observed in several instances. The injected animals appeared to be less active than the normal controls.

Several deaths occurred during the first ten days, some from intercurrent pneumonias, others from undetermined causes. On the tenth day eight kittens and four rabbits with well-developed hydrocephalus were alive and in good condition. These were used for the injection of the ventricles.

The animals were divided into two groups, one group receiving a 2 per cent solution of equal parts of potassium ferrocyanide and iron ammonium citrate, the other group a $\frac{1}{10}$ per cent solution of trypan blue. The experimental procedure was as follows: The skin of the head was shaved and cleansed, a sharp, 26gauge needle was inserted through the skin and bone into one of the lateral ventricles, and two drops of fluid were permitted to escape, whereupon an antitoxin syringe was coinected with the needle and an equal quantity of potassium ferrocyanide and iron ammonium citrate or trypan blue was injected. The needle was removed and the animal released. The animals receiving potassium ferrocyanide and iron ammonium citrate were killed at intervals varying from thirty minutes to two hours, those receiving trypan blue at intervals from eight to twenty-four hours. The brains injected with potassium ferrocyanide and iron ammonium citrate were fixed in 10 per cent formalin plus 1 per cent hydrochloric acid. The acid precipitated the ferro- 
cyanide and citrate solutions as Prussian blue. The brains which had been injected with trypan blue were fixed in 10 per cent formalin without the addition of acid. The fixation was accomplished by immersion, in order to avoid the disturbing factors of intra-arterial injection.

On gross inspection, the surfaces of the brains were found either unstained or very faintly colored. On cutting thin coronal

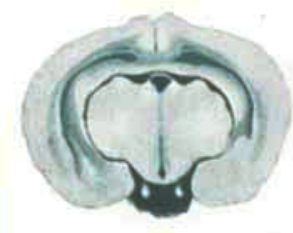

1

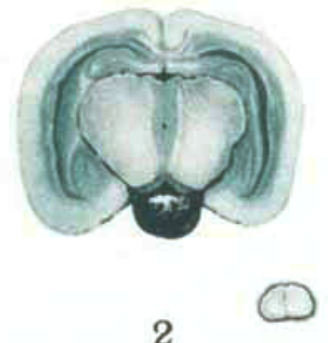

2

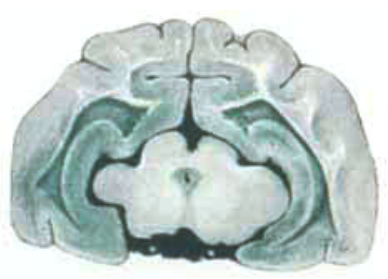

3

Fig. 1 Cross-section of the brain of a young rabbit in which dilatation of the ventricles had resulted from the injection of lampblack in to the eisterna cerebellomedullaris. Subsequently a solution of potassium ferrocyanide and iron ammonium citrate was injected by replacement into a lateral ventricle. The animal was killed two hours later and the brain fixed. A zone of Prussian-blue-stained brain tissue can be seen surrounding the ventricles.

Fig. 2 Cross-section of the brain of a young rabbit in which dilatation of the ventricles has been similarly brought about. Trypan blue was injected into the ventricles of this animal. A zone of stained tissue can be seen surrounding the ventricles. The insert shows a section of the lumbar cord from the same animal. The wall of the central canal and a zone of tissue surrounding it are faintly stained.

Fig. 3 Cross-section of the brain of a young cat, showing the dilated ventricles into which a solution of potassium ferrocyanide and iron ammonium citrate was injected. A zone of Prussian-blue-stained tissue is seen surrounding the ventricles.

sections of the brains and cords a striking appearance was disclosed. The ventricles, as was expected, showed varying degrees of distention. The walls of the ventricles and a zone of surrounding brain tissue to a depth of several millimeters were deeply stained (figs. 1, 2, and 3). This zone of staining enclosed not only the lateral and third ventricles, but the aqueduct of Sylvius, the fourth ventricle and central canal of the cord, demonstrating a free communication between all of the cerebral ventricles and 
the central canal. The inner portion of the zone of staining adjacent to the ventricles was most deeply colored, while towards the surface of the brain the stain became gradually paler. It is noteworthy that the stains had penetrated even into the most caudal recess of the central canal of the cord (fig. 2).

Microscopically, the dyes were readily visible in the tissues of the brain. Precipitated Prussian-blue granules were found in the tissues surrounding the ventricles. The precipitate occurred in the intercellular spaces, in the perineuronal spaces and to a large extent in the perivascular sheaths. Prussian blue was precipitated in minute granules in the cytoplasm of the ependymal cells. None of the precipitate was found to be intracellular, either in glial or nerve cells. The choroid plexuses did not appear to have been penetrated by the coloring matter.

The distribution of trypan blue differed microscopically somewhat from that of the Prussian blue. The choroid plexuses appeared entirely unstained. Precipitated trypan blue was visible on the surface of the ependymal cells in some areas, but none was discernible in the cytoplasm of the cells. Trypan blue could not be seen in the intercellular spaces or in the perineuronal spaces. Many of the glial cells contained dust-like particles of dye within their cytoplasm. Trypan blue was not visible in the cytoplasm of any of the nerve cells. The small vessels and capillaries in the zone of staining were noteworthy in the trypan-blue animals. Brilliantly stained cells containing numerous granules of the dye in their cytoplasm everywhere surrounded the blood-vessels (fig. 4). These cells which closely invest the blood-vessels belong to the category of adventitial cells or macrophages. They are extremely phagocytic and are the scavenger cells of the brain tissue, which have been repeatedly shown to play a prominent rôle in brain injury and repair.

The microscopic distribution of these substances indicates that they have followed definite pathways in their escape from the dilated ventricles. The solutions are observed in their escape through the ependyma into the intercellular spaces and thence into the perivascular sheaths. These observations lead to the conclusion that fluid currents exist between the dilated ventricles 
and the neighboring vessels, under the abnormal conditions of a heightened intraventricular pressure.

It remains to be pointed out that there is no evidence microscopically that the substances behave as a fixative would if similarly injected. Neither of the reagents employed in these experiments appears to exert any deleterious influence on the cells which it encounters during its passage into the brain tissues. Nuclear staining or diffuse discoloration of the brain tissue, which would be indicative of cell injury and death, are not

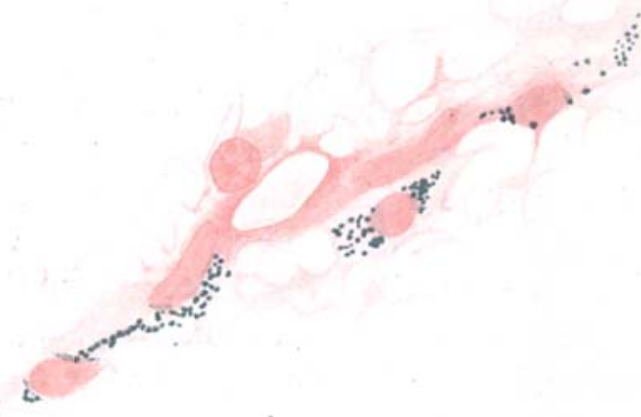

4

Fig. 4 Microscopic section of the cortex of the left hemisphere of a rabbit in which trypan blue had been injected into the dilated ventricles. A portion of a small cerebral vessel is shown, surrounding which are several phagocytic cells containing granules of trypan blue.

observed. The phenomena of distribution of the dye granules must be looked upon not as the result of diffusion of a foreign chemical through dead tissue, but as a true passage of the dyes through the brain tissue during life. The explanation for the different findings with the ferrocyanide-citrate solution and with the trypan blue lies in the fact that microscopic identification of the former requires only the action of the mineral acid, while vital activity on the part of a certain class of phagocytic cells is necessary for the intracellular aggregation of the vital-dye particles before microscopic identification is possible. As illustrating microscopically the pathway of absorption, the 
ferrocyanide-citrate method possesses the advantage of freedom from the modifying influences of cell activity; the findings with trypan blue, however, in these experiments indicate the ultimate, if not the total, pathway of absorption of a colloidal suspension from the dilated cerebral ventricle.

\section{SUMMARY}

Hydrocephalus was produced in a number of kittens and young rabbits by injecting a suspension of lampblack into the cisterna cerebellomedullaris. Subsequently a readily diffusible solution or a colloidal dye was injected into the dilated ventricles. The experiments show that absorption occurs to some extent from the ventricles in hydrocephalic animals and that the pathway of escape is through the ependyma into the intercellular spaces and finally into the perivascular spaces. The rate of diffusion of a true solution (potassium ferrocyanide and iron ammonium citrate) from the cerebral chambers into the brain substance is fairly rapid, but that of a collodial suspension (trypan blue) is somewhat slower. No observations on the rapidity of absorption of the foreign substances into the cerebral capillaries were made. No evidence of absorption by the choroid plexuses was obtained. 


\section{LITERATURE CITED}

Dandy, W. F., and Blackfan, K. D. 1913 An experimental and clinical study of internal hydrocephalus. Jour. Am. Med. Assoc., vol. 61, p. 2216. 1914 Internal hydrocephalus: An experimental, clinical and pathological study. Am. Jour. Diseases of Children, vol. 8, p. 406.

1917 Internal hydrocephalus - second paper. Am. Jour. Diseases of Children, vol. 14, p. 424.

Dandy, W. E. 1919 Experimental hydrocephalus. Annals of Surgery, vol. 70, p. 129.

Thomas, W. S. 1914 Experimental hydrocephalus. Jour. Exper. Med., vol. 19 , p. 106.

WEED, L. H. 1920 The experimental production of an internal hydrocephalus, The Carnegie Institution of Washington. Contribution to Embryology. no. 44. 